\title{
Assessing Multi-Micronutrients Deficiency in Agricultural Soils of India
}

\author{
Arvind Kumar Shukla ${ }^{1}$, Sanjib Kumar Behera ${ }^{1, * \mathbb{D}}$, Chandra Prakash ${ }^{1}$, Ashok Kumar Patra ${ }^{1}$, Ch Srinivasa Rao $^{2}$, \\ Suresh Kumar Chaudhari ${ }^{3}$, Soumitra Das ${ }^{4}$, Anil Kumar Singh ${ }^{3}$ and Andrew Green ${ }^{5}$ \\ 1 ICAR-Indian Institute of Soil Science, Bhopal 462038, India; arvind.shukla@icar.gov.in (A.K.S.); \\ n.cpsharma@gmail.com (C.P.); Ashok.Patra@icar.gov.in (A.K.P.) \\ 2 ICAR-National Academy of Agricultural Research Management, Telangana 500030, India; \\ director@naarm.org.in \\ 3 Indian Council of Agricultural Research, New Delhi 110012, India; Suresh.Chaudhari@icar.gov.in (S.K.C.); \\ aksingh.icar@gmail.com (A.K.S.) \\ 4 International Zinc Association, New Delhi 110062, India; sdas@zinc.org \\ 5 International Zinc Association, Durham, NC 27713, USA; agreen@zinc.org \\ * Correspondence: sanjibkumarbehera123@gmail.com
}

Citation: Shukla, A.K.; Behera, S.K.; Prakash, C.; Patra, A.K.; Rao, C.S.; Chaudhari, S.K.; Das, S.; Singh, A.K.; Green, A. Assessing Multi-Micronutrients Deficiency in Agricultural Soils of India. Sustainability 2021, 13, 9136. https:// doi.org/10.3390/su13169136

Academic Editor: Jan Hopmans

Received: 4 August 2021

Accepted: 9 August 2021

Published: 15 August 2021

Publisher's Note: MDPI stays neutral with regard to jurisdictional claims in published maps and institutional affiliations.

Copyright: (c) 2021 by the authors. Licensee MDPI, Basel, Switzerland. This article is an open access article distributed under the terms and conditions of the Creative Commons Attribution (CC BY) license (https:/ / creativecommons.org/licenses/by/ $4.0 /)$.

\begin{abstract}
The deficiencies of nutrient elements and inappropriate nutrient management practices in agricultural soils of the world is one of the reasons for low crop productivity, reduced nutritional quality of agricultural produce, and animal/human malnutrition. We carried out the present study to evaluate the single and multi-nutrient deficiencies of sulfur (S) and micronutrients (zinc (Zn), boron (B), iron (Fe), copper (Cu) and manganese $(\mathrm{Mn})$ ) in agricultural soils of India for their effective management to achieve sustainable crop production, improved nutritional quality in crops and better animal/human health. Altogether, 24,2827 surface soil samples (0 to $15 \mathrm{~cm}$ depth) were collected from the agriculture fields of 615 districts in 28 states of India and were analyzed for available S and micronutrient concentration. The concentration of available $S$ and micronutrients varied widely. There were variable and widespread deficiencies of $S$ and micronutrients in different states. The deficiencies of $\mathrm{S}, \mathrm{Zn}$ and $\mathrm{B}$ were higher compared to the deficiencies of $\mathrm{Fe}, \mathrm{Cu}$ and $\mathrm{Mn}$. There were occurrences of two-nutrient (namely $S+Z n, Z n+B, S+B, Z n+F e ~ Z n+M n, S+F e, ~ Z n+C u$ and $\mathrm{Fe}+\mathrm{B}$ ), three-nutrient (namely $\mathrm{S}+\mathrm{Zn}+\mathrm{B}, \mathrm{S}+\mathrm{Zn}+\mathrm{B}$ and $\mathrm{Zn}+\mathrm{Fe}+\mathrm{B}$ ) and four-nutrient (namely $\mathrm{Zn}+\mathrm{Fe}+\mathrm{Cu}+\mathrm{Mn}$ and $\mathrm{Zn}+\mathrm{Fe}+\mathrm{Cu}+\mathrm{Mn}+\mathrm{B}$ ) deficiencies in different extents. This information could be used by various stakeholders for production, supply and application of the right kind of fertilizers in different districts, states and agro-ecological regions of India for better crop production, crop nutritional quality, nutrient use efficiency and soil and environmental health. This will also help in a greater way to address the issue of malnutrition in human/animals.
\end{abstract}

Keywords: micronutrients; available sulfur; tropical soil; soil health; human health

\section{Introduction}

Soils are the prime sources of nutrients for plant growth and development [1,2]. Plants absorb the desired nutrients from soil in different proportions as per requirements $[3,4]$. Phytomicrobiome (microbial community associated with plant) play a pivotal role in enhancing nutrient availability and crop yield [5,6]. Soil is linked to the well-being of animals and humans through agriculture and agricultural produces [7]. Macronutrients are required in higher quantities by the plants whereas micronutrients (otherwise called as trace elements) are needed in smaller quantities but both the categories of nutrients play equally important roles in plant metabolism. The deficiency of phyto-available (hereafter referred as available) nutrients in soils adversely affect soil health, crop production, nutritional quality of agricultural produces and in turn, human/animal health [8,9].

Besides nitrogen $(\mathrm{N})$, phosphorus $(\mathrm{P})$ and potassium $(\mathrm{K})$ deficiency, deficiencies of sulfur $(\mathrm{S})[10,11]$ and micronutrients (zinc $(\mathrm{Zn})$, boron $(\mathrm{B})$, iron $(\mathrm{Fe})$, copper $(\mathrm{Cu})$ and 
manganese (Mn)) (either single nutrient deficiency or multi-nutrient deficiency) have been reported in different soils of the world, including in India [12-14]. The essential micronutrients for field crops are $\mathrm{Zn}, \mathrm{B}, \mathrm{Fe}, \mathrm{Cu}, \mathrm{Mn}$ and molybdenum [15]. Other micronutrients at low concentrations considered essential for some plants are nickel and cobalt. The incidence of micronutrient deficiencies in crops and soils has increased markedly in recent years. The emergence of micronutrient deficiencies in soils of different parts of the world is primarily due to cultivation of high-yielding crops and cultivars, increased cropping intensity, enhanced application of high-analysis ( $>30 \%$ of available nutrients) NPK fertilizers having lower amounts of micronutrient contaminants, less or no use of organic manures and increased use of advanced soil and plant analysis technologies [15]. The extent of $S$ and micronutrient deficiencies vary within different administrative boundaries such as districts and states because of the variations in soil types, prevailing climatic conditions, nature and type of crops and soil-crop management practices $[8,16]$. The intake of foods (obtained from crops) low in micronutrient concentration and produced from micronutrient-deficient soils causes micronutrient malnutrition in animals and humans [14,17]. However, adoption of agronomic biofortification strategies such as application of micronutrients to soil and crops (as foliar spray) has the potential to ameliorate micronutrient deficiencies in soilplant systems, and to enhance crop productivity and micronutrient content in agricultural produce, which could alleviate micronutrient malnutrition in animals and humans [18].

There is a need for continuous evaluation and monitoring of the extent of $S$ and micronutrient deficiencies in agricultural soils, at the district and state levels, for the production and supply of the right kind and quantity of $S$ and micronutrient fertilizers and the adoption of appropriate site-specific $S$ and micronutrient management practices [14,19]. The mapping of $\mathrm{S}$ and micronutrient deficiencies in soils using geostatistical tools is useful for proper visualization of location and/or area-wise deficiencies [20]. These maps are useful for taking decisions regarding the application of required nutrients in right quantity, appropriate form and in the right place and in balanced proportions for obtaining the higher nutrient use efficiency. The efficient $S$ and micronutrient management practices in soil-plant systems help in sustainable crop production, production of better-quality agricultural produce and in turn, improve animal and human health $[7,9,21,22]$.

Although there are many scattered studies evaluating the status and distribution of $S$ and micronutrient deficiency, systematic information regarding state-wise $\mathrm{S}$ and micronutrient deficiencies and the status of two- or multiple-nutrient deficiencies in cultivated soils of India is limited. We hypothesize that a wide variation exists in the state-wise $\mathrm{S}$ and micronutrient deficiencies in India. Therefore, the present study was carried out with the aim to evaluate the status of single- and multi-nutrient deficiencies of $S$ and micronutrients and to visualize their distribution in agricultural soils of different states of India. This information is useful for adopting efficient $\mathrm{S}$ and micronutrient management practices in different agricultural soils of India.

\section{Materials and Methods}

\subsection{Study Area}

The study area (India) is located at $8^{\circ} 4^{\prime}-37^{\circ} 6^{\prime} \mathrm{N}$ latitude and $68^{\circ} 7^{\prime}-97^{\circ} 25^{\prime} \mathrm{E}$ longitude and is surrounded by the Indian Ocean (on the south), the Arabian Sea (on the southwest) and the Bay of Bengal (on the southeast). It shares its land borders with Pakistan, China, Bhutan, Bangladesh, Myanmar and Nepal. India is the bulk of the Indian subcontinent lying on Indian tectonic plate, which is a portion of Indo-Australian plate. It comprises 28 states and eight union territories. Soils of the country are alluvial, black, red and yellow, lateritic, arid, forest and mountainous, and are formed by deposition of sediments of rivers. Soils belong to mainly to the orders of Inceptisols, Alfisols, Entisols, Vertisols, Mollisols, Aridisols, Ultisols and Oxisols, with sandy to clayey texture [23]. The climate of the country is influenced by the Himalayas and the Thar Desert. India has arid, semi-arid, tropical wet, tropical wet-dry, humid sub-tropical and alpine climatic zones with mean temperature of $<20.0->27.5^{\circ} \mathrm{C}$ prevailing across the country. The country is divided into 
20 agro-ecological regions (AER) with different climate parameters (Table 1), soils and cultivated crops (Table 2) [24]. The mean annual rainfall varies from $<150-3000 \mathrm{~mm}$ in different AERs. It receives uneven and erratic rainfall from June to September. It rains heavily in the north-eastern and western ghats regions and Kerala state, whereas the south-eastern parts and the Indo-Gangetic plain receive moderate rainfall. Scanty rainfall is obtained in the western parts of Gujarat, Rajasthan, Punjab and Haryana.

Table 1. Different agro-ecological regions of India with climate parameters.

\begin{tabular}{|c|c|}
\hline $\begin{array}{c}\text { Serial No. of } \\
\text { Agro-Ecological Region }\end{array}$ & Name of Agro-Ecological Region \\
\hline 1 & $\begin{array}{l}\text { Cold arid eco-region with shallow } \\
\text { skeletal soils }\end{array}$ \\
\hline 2 & $\begin{array}{l}\text { Hot arid eco-region with desert and } \\
\text { saline soils }\end{array}$ \\
\hline 3 & $\begin{array}{l}\text { Hot arid eco-region with red and } \\
\text { black soils }\end{array}$ \\
\hline 4 & $\begin{array}{l}\text { Hot semi-arid eco-region with } \\
\text { alluvium derived soils }\end{array}$ \\
\hline 5 & $\begin{array}{l}\text { Hot semi-arid eco-region with } \\
\text { medium and deep black soils }\end{array}$ \\
\hline 6 & $\begin{array}{l}\text { Hot semi-arid eco-region with } \\
\text { shallow and medium (dominant) } \\
\text { black soils }\end{array}$ \\
\hline 7 & $\begin{array}{l}\text { Hot semi-arid eco-region with red } \\
\text { and black soils }\end{array}$ \\
\hline 8 & $\begin{array}{l}\text { Hot semi-arid eco-region with red } \\
\text { loamy soils }\end{array}$ \\
\hline 9 & $\begin{array}{l}\text { Hot sub-humid (dry) eco-region with } \\
\text { alluvial-derived soils }\end{array}$ \\
\hline 10 & $\begin{array}{l}\text { Hot sub-humid eco-region with red } \\
\text { and black soils }\end{array}$ \\
\hline 11 & $\begin{array}{l}\text { Hot sub-humid eco-region with red } \\
\text { and yellow soils }\end{array}$ \\
\hline 12 & $\begin{array}{l}\text { Hot sub-humid eco-region with red } \\
\text { and lateritic soils }\end{array}$ \\
\hline 13 & $\begin{array}{l}\text { Hot sub-humid (moist) eco-region } \\
\text { with alluvium-derived soils }\end{array}$ \\
\hline 14 & $\begin{array}{l}\text { Warm sub-humid to humid with } \\
\text { inclusion of perhumid eco-region } \\
\text { with brown forest and podzolic soils }\end{array}$ \\
\hline 15 & $\begin{array}{l}\text { Hot sub-humid (moist) to humid } \\
\text { (inclusion of perhumid) eco-region } \\
\text { with alluvium-derived soils }\end{array}$ \\
\hline 16 & $\begin{array}{l}\text { Warm sub-humid eco-region with } \\
\text { brown and red hill soils }\end{array}$ \\
\hline 17 & $\begin{array}{l}\text { Warm perhumid eco-region with red } \\
\text { and lateritic soils }\end{array}$ \\
\hline 18 & $\begin{array}{l}\text { Hot sub-humid to semi-arid } \\
\text { eco-region with coastal } \\
\text { alluvium-derived soils }\end{array}$ \\
\hline 19 & $\begin{array}{c}\text { Hot humid perhumid eco-region with } \\
\text { red, lateritic and } \\
\text { alluvium-derived soils }\end{array}$ \\
\hline 20 & $\begin{array}{l}\text { Hot humid per-humid island } \\
\text { eco-region with red loamy and } \\
\text { sandy soils }\end{array}$ \\
\hline
\end{tabular}

\section{Climate Parameters}

It experiences mild summer, harsh winter and receives mean annual rainfall of $<150 \mathrm{~mm}$.

It experiences hot summer and cool winter and receives mean annual rainfall of $<400 \mathrm{~mm}$.

It experiences hot and dry summer, mild winter and receives mean annual rainfall of $400-500 \mathrm{~mm}$.

It experiences hot and dry summer, cool winter and receives mean annual rainfall of 500-1000 $\mathrm{mm}$.

It experiences hot and wet summer, dry winter and receives mean annual rainfall of 500-1000 mm.

It experiences hot and humid summer, mild and dry winter and receives mean annual rainfall of 600-1000 mm.

It experiences hot and dry summer, mild and dry winter and receives mean annual rainfall of $600-1100 \mathrm{~mm}$.

It experiences hot and dry summer, mild winter and receives mean annual rainfall of $600-1000 \mathrm{~mm}$.

It experiences hot summer, cool winter and receives mean annual rainfall of 1000-1200 $\mathrm{mm}$.

It experiences hot summer, mild winter and receives mean annual rainfall of 1000-1500 $\mathrm{mm}$.

It experiences hot summer, cool winter and receives mean annual rainfall of $1200-1600 \mathrm{~mm}$.

It experiences hot summer, cool winter and receives mean annual rainfall 1000-1600 $\mathrm{mm}$.

It experiences hot and wet summer, cool and dry winter and receives mean annual rainfall of $1400-1800 \mathrm{~mm}$.

It experiences mild summer, cool winter and receives mean annual rainfall of 1000-2000 mm.

It experiences hot summer, mild to moderately cool winter and receives mean annual rainfall of 1400-1600 mm.

It experiences warm summer, cool winter and receives mean annual rainfall of $2000 \mathrm{~mm}$.

It experiences warm summer, cool winter and receives mean annual rainfall of 2000-3000 $\mathrm{mm}$.

It experiences semi-arid and sub-humid (moist) climate and receives mean annual rainfall of $900-1100 \mathrm{~mm}$ (west coast) and 1200-1600 $\mathrm{mm}$ (east coast).

It experiences hot and humid summer, warm winter and receives mean annual rainfall of $>2000 \mathrm{~mm}$.

It experiences tropical climate and receives mean annual rainfall of 1600-3000 $\mathrm{mm}$. 
Table 2. Nature of soils and commonly cultivated crops in different agro-ecological regions of India.

\begin{tabular}{|c|c|c|}
\hline $\begin{array}{l}\text { Serial No. of } \\
\text { Agro-Ecological Region }\end{array}$ & Nature of Soil & Commonly Cultivated Crops \\
\hline 1 & $\begin{array}{c}\text { Soils are skeletal, calcareous and alkaline } \\
\text { in reaction. }\end{array}$ & $\begin{array}{l}\text { Vegetables, millets, wheat, fodder, pulses } \\
\text { and barley. }\end{array}$ \\
\hline 2 & $\begin{array}{c}\text { Soils are sandy, moderately calcareous and } \\
\text { alkaline in reaction. }\end{array}$ & $\begin{array}{l}\text { Pearl millet, fodder, pulses, cotton, sugarcane, } \\
\text { mustard, wheat and gram. }\end{array}$ \\
\hline 3 & $\begin{array}{c}\text { Soils are shallow, medium red soil with slightly } \\
\text { acidic and noncalcareous nature. Soils are also } \\
\text { deep, clayey black with slightly alkaline and } \\
\text { calcareous nature. }\end{array}$ & $\begin{array}{l}\text { Pearl millet, groundnut, sugarcane, sunflower } \\
\text { and cotton. }\end{array}$ \\
\hline 4 & $\begin{array}{l}\text { Soils are deep, loamy and alluvium derived and } \\
\text { clayey mixed red and black. }\end{array}$ & $\begin{array}{l}\text { Rice, millets, maize, pulses, berseem, wheat, } \\
\text { mustard and sugarcane, jowar, pigeon pea, } \\
\text { soybean, lentil and cotton. }\end{array}$ \\
\hline 5 & $\begin{array}{l}\text { Soils are deep loamy to clayey black soil with } \\
\text { slightly alkaline and calcareous nature with } \\
\text { swell-shrink characters. }\end{array}$ & $\begin{array}{l}\text { Sorghum, pearl millet, pigeon pea, groundnut, } \\
\text { soybean, maize, pulses, safflower, sunflower } \\
\text { and wheat. }\end{array}$ \\
\hline 6 & $\begin{array}{l}\text { Soils are shallow, loamy skeletal, clayey, } \\
\text { calcareous and moderately alkaline in reaction. }\end{array}$ & $\begin{array}{l}\text { Sorghum, pearl millet, pigeon pea, safflower, } \\
\text { sunflower, cotton and groundnut. }\end{array}$ \\
\hline 7 & $\begin{array}{l}\text { Soils are red, non-calcareous and neutral } \\
\text { in reaction, clayey and calcareous with alkaline } \\
\text { in reaction. }\end{array}$ & $\begin{array}{l}\text { Sorghum, pigeon pea, rice, cotton, groundnut, } \\
\text { sunflower, safflower, castor. }\end{array}$ \\
\hline 8 & $\begin{array}{l}\text { Soils are non-calcareous and slightly acidic soil, } \\
\text { and calcareous and moderately alkaline. }\end{array}$ & $\begin{array}{c}\text { Millets, pulses, groundnut, sorghum } \\
\text { and sunflower. }\end{array}$ \\
\hline 9 & $\begin{array}{l}\text { Soils are alluvium derived deep and loamy with } \\
\text { neutral in reaction. }\end{array}$ & $\begin{array}{l}\text { Rice, maize, barley, pigeon pea, jute, wheat, } \\
\text { lentil, mustard, cotton and sugarcane. }\end{array}$ \\
\hline 10 & $\begin{array}{l}\text { Soils are deep black calcareous soil with slightly } \\
\text { alkaline in reaction, moderately deep, clayey red } \\
\text { with neutral to slightly acidic in reaction. }\end{array}$ & $\begin{array}{l}\text { Rice, wheat, sorghum, soybean, pigeon pea, } \\
\text { gram, cotton and vegetables. }\end{array}$ \\
\hline 11 & $\begin{array}{c}\text { Soils are deep, loamy, non-calcareous, red and } \\
\text { yellow with neutral to slightly alkaline } \\
\text { in reaction. }\end{array}$ & $\begin{array}{l}\text { Rice, wheat, millets, pigeon pea, green gram and } \\
\text { black gram. }\end{array}$ \\
\hline 12 & $\begin{array}{l}\text { Soils are fine loamy to clayey, non-calcareous red } \\
\text { soil with slightly to moderately acidic in reaction. }\end{array}$ & Rice, wheat, pulses and groundnut. \\
\hline 13 & $\begin{array}{l}\text { Soils are deep, loamy, calcareous with } \\
\text { moderately alkaline in reaction. }\end{array}$ & $\begin{array}{l}\text { Rice, maize, moong, pigeon pea, lentil, wheat, } \\
\text { sesamum, groundnut, sugarcane, tobacco, } \\
\text { turmeric, chilies, potato and coriander. }\end{array}$ \\
\hline 14 & $\begin{array}{l}\text { Soils are shallow to deep brown forest and } \\
\text { podzolic soil, fine loamy and neutral to mildly } \\
\text { alkaline in reaction. }\end{array}$ & Wheat, millet, maize, rice and apple. \\
\hline 15 & Soils are slight to strongly acidic. & $\begin{array}{l}\text { Rice, wheat, jute, tea, pineapple, citrus, banana, } \\
\text { pulses, oilseed and sugarcane. }\end{array}$ \\
\hline 16 & $\begin{array}{l}\text { Soils are shallow to moderately shallow, loamy } \\
\text { brown forest soil with moderately acidic } \\
\text { in reaction. }\end{array}$ & $\begin{array}{c}\text { Rice, maize, millet, potato, sweet potato, } \\
\text { sesamum, pulses, cotton, mesta, sugarcane, } \\
\text { pineapple, citrus, apple, pear, peach, banana and } \\
\text { medicinal plants. }\end{array}$ \\
\hline 17 & $\begin{array}{l}\text { Soils are shallow to very deep, loamy, red and } \\
\text { lateritic, red and yellow with acidic in reaction. }\end{array}$ & $\begin{array}{c}\text { Rice, millets, maize, potato, tea, coffee, rubber, } \\
\text { orange, pineapple, jute, mustard, black gram, } \\
\text { green gram and lentil. }\end{array}$ \\
\hline 18 & Soils are clayey and slight to moderately sodic. & $\begin{array}{l}\text { Rice, coconut, black gram, lentil, sunflower } \\
\text { and groundnut. }\end{array}$ \\
\hline 19 & $\begin{array}{l}\text { Soils are deep, clayey red, lateritic, alluvium } \\
\text { derived and strongly to moderately acidic } \\
\text { in reaction. }\end{array}$ & Rice, tapioca, coconut and spices. \\
\hline 20 & $\begin{array}{l}\text { Soils are medium to very deep red-loamy, } \\
\text { marine-derived, calcareous sandy with slightly } \\
\text { to strongly acidic in reaction. }\end{array}$ & $\begin{array}{l}\text { Rice, coconut, arecanut, oil palm, tapioca } \\
\text { and pepper. }\end{array}$ \\
\hline
\end{tabular}




\subsection{Soil Sampling and Analysis}

Altogether, 242,827 soil samples from the surface soil layers ( 0 to $15 \mathrm{~cm}$ depth) were collected from agricultural land holdings of 615 districts in 28 states of India, under the tutelage of All India Coordinated Research Project on Micro and Secondary Nutrients and Pollutant Elements in Soils and Plants, following a stratified random sampling procedure [25], from April to June of 2012 to 2018. Soil samples were collected using a hand-held auger composed of stainless steel. Each composite soil sample was obtained from 3 to 4 subsamples collected from a small land holding $(<1$ ha), 6 to 7 subsamples collected from a medium land holding (1-3 ha) and 9 to 10 subsamples collected from a large land holding $(>3 \mathrm{ha}$ ) of each district. The collected samples were air dried, processed, ground to pass through a $2 \mathrm{~mm}$ size sieve and stored in plastic bottles for analysis.

Soil samples were analyzed for available $S$ using calcium chloride solution $(0.15 \%)$ as extractant [26] and spectrophotometer (Shimadzu (UV-1800), Shimadzu Scientific Instruments, Columbia, USA) for estimation. Available $\mathrm{Zn}, \mathrm{Fe}, \mathrm{Cu}$ and $\mathrm{Mn}$ in soil samples were determined after extracting the samples with diethylene triamine penta acetic acid extractant [27]. The estimation of $\mathrm{Zn}, \mathrm{Fe}, \mathrm{Cu}$ and $\mathrm{Mn}$ in clear extract was carried out utilizing atomic absorption spectrophotometer (Varian (AA240FS), Varian Inc., Palo Alto, CA, USA). Available B was estimated after extracting the samples with hot water [28] and estimating the color intensity developed by adding azomethine- $\mathrm{H}$ solution using a spectrophotometer (Shimadzu (UV-1800), Shimadzu Scientific Instruments, Columbia, Portland, OR, USA).

\subsection{Statistical Analysis}

The data pertaining to available $\mathrm{S}, \mathrm{Zn}, \mathrm{B}, \mathrm{Fe}, \mathrm{Cu}$ and $\mathrm{Mn}$ in soil samples were subjected to statistical analysis for obtaining descriptive statistics, viz., minimum, maximum, mean, standard deviation (SD), coefficient of variation (CV), skewness and kurtosis, using SAS 9.2 software package [29]. Run tests were carried out to check the randomness of data. The frequency distribution of soil samples having available $S$ and micronutrients in different concentrations and distribution of single- and multi-nutrient deficiencies were estimated using the data analysis program of Microsoft Excel. The concentrations of $S$ and micronutrients in soil samples were categorized as acute deficient, deficient, latent deficient, marginally sufficient, adequate and high as per the generalized classification adopted for Indian soils [16]. The distribution maps for two- and multi-nutrient deficiencies were prepared using software ArcGIS for power BI, in order to have better data visualization and proper understanding of distribution of nutrient deficiencies in the different parts of India. The nutrient deficiencies (\% of the sampled sites), district boundary, state boundary and AER boundary were used as different layers of ArcGIS mapping.

\section{Results}

\subsection{Concentration of Available S, Zn, B, Fe, Cu and $\mathrm{Mn}$}

The concentration of available $\mathrm{S}, \mathrm{Zn}$ and $\mathrm{B}$ varied from $0.02-822,0.01-59.8$ and 0.01-109 $\mathrm{mg} \mathrm{kg}^{-1}$, respectively (Table 3). The concentration of available $\mathrm{Fe}, \mathrm{Cu}$ and $\mathrm{Mn}$ varied from $0.01-964,0.01-99.2$ and $0.01-483 \mathrm{mg} \mathrm{kg}^{-1}$, respectively. However, the mean concentration of available nutrients followed the order: available $\mathrm{Fe}>$ available $\mathrm{S}>$ available $\mathrm{Mn}>$ available $\mathrm{Cu}>$ available $\mathrm{Zn}$, available $\mathrm{B}$ (Figure 1). The $\mathrm{CV}$ values of available nutrients varied from $111 \%$ (for available S) to $338 \%$ (for available B).

\subsection{Distribution of Single Nutrient Deficiencies of $S, \mathrm{Zn}, \mathrm{B}, \mathrm{Fe}, \mathrm{Cu}$ and $\mathrm{Mn}$}

The concentration of available nutrients in soils were grouped into acute deficient, deficient, latent deficient, marginally sufficient, adequate and high categories. About $11.4 \%, 29.4 \%$ and $17.8 \%$ of the sampled sites were acute deficient $\left(\leq 7.5 \mathrm{mg} \mathrm{kg}^{-1}\right)$, deficient $\left(>7.5-\leq 15.0 \mathrm{mg} \mathrm{kg}^{-1}\right)$ and latent deficient $\left(>15.0-\leq 22.5 \mathrm{mg} \mathrm{kg}^{-1}\right)$ in available $\mathrm{S}$, respectively (Figure 2). Meanwhile, $12.1 \%, 11.6 \%$ and $17.7 \%$ of the sampled sites were marginally sufficient $\left(>22.5-\leq 30.0 \mathrm{mg} \mathrm{kg}^{-1}\right)$, adequate $\left(>30.0-\leq 40.0 \mathrm{mg} \mathrm{kg}^{-1}\right)$ and high $\left(>40.0 \mathrm{mg} \mathrm{kg}^{-1}\right)$ in available S. Out of 615 districts, $>30-\leq 40 \%$ of the sampled sites in 
86 districts, $>40-\leq 50 \%$ of the sampled sites in 70 districts and $>50 \%$ of the sampled sites in 101 districts were deficient (acute deficient + deficient) in available S. More than $50 \%$ of the sampled sites in 12 districts of Gujarat, 13 districts of Madhya Pradesh and 8 districts each in Odisha and Tamil Nadu were deficient in available S.

Table 3. Descriptive statistics of available sulfur and micronutrients in soils the India $(n=242827)$.

\begin{tabular}{cccccccc}
\hline Nutrients & Minimum & Maximum & Mean & SD & CV (\%) & Skewness & Kurtosis \\
\hline $\mathrm{S}\left(\mathrm{mg} \mathrm{kg}^{-1}\right)$ & 0.02 & 822 & 27.0 & 29.9 & 111 & 4.28 & 35.6 \\
$\mathrm{Zn} \mathrm{(mg} \mathrm{kg}$ & -1 \\
$\mathrm{~B}\left(\mathrm{mg} \mathrm{kg}^{-1}\right)$ & 0.01 & 59.8 & 1.40 & 1.60 & 118 & 7.35 & 118 \\
$\mathrm{Fe}\left(\mathrm{mg} \mathrm{kg}^{-1}\right)$ & 0.01 & 109 & 1.40 & 4.70 & 338 & 12.8 & 189 \\
$\mathrm{Cu}\left(\mathrm{mg} \mathrm{kg}^{-1}\right)$ & 0.01 & 964 & 31.0 & 52.2 & 168 & 5.53 & 47.3 \\
$\mathrm{Mn}\left(\mathrm{mg} \mathrm{kg}^{-1}\right)$ & 0.01 & 99.2 & 2.30 & 3.50 & 153 & 10.8 & 186 \\
\hline
\end{tabular}

Note: $\mathrm{S}=$ available sulfur, $\mathrm{Zn}=$ available zinc, $\mathrm{B}=$ available boron, $\mathrm{Fe}=$ available iron, $\mathrm{Cu}=$ available copper, $\mathrm{Mn}=$ available manganese, $\mathrm{SD}=$ standard deviation, $\mathrm{CV}=$ coefficient of variation .

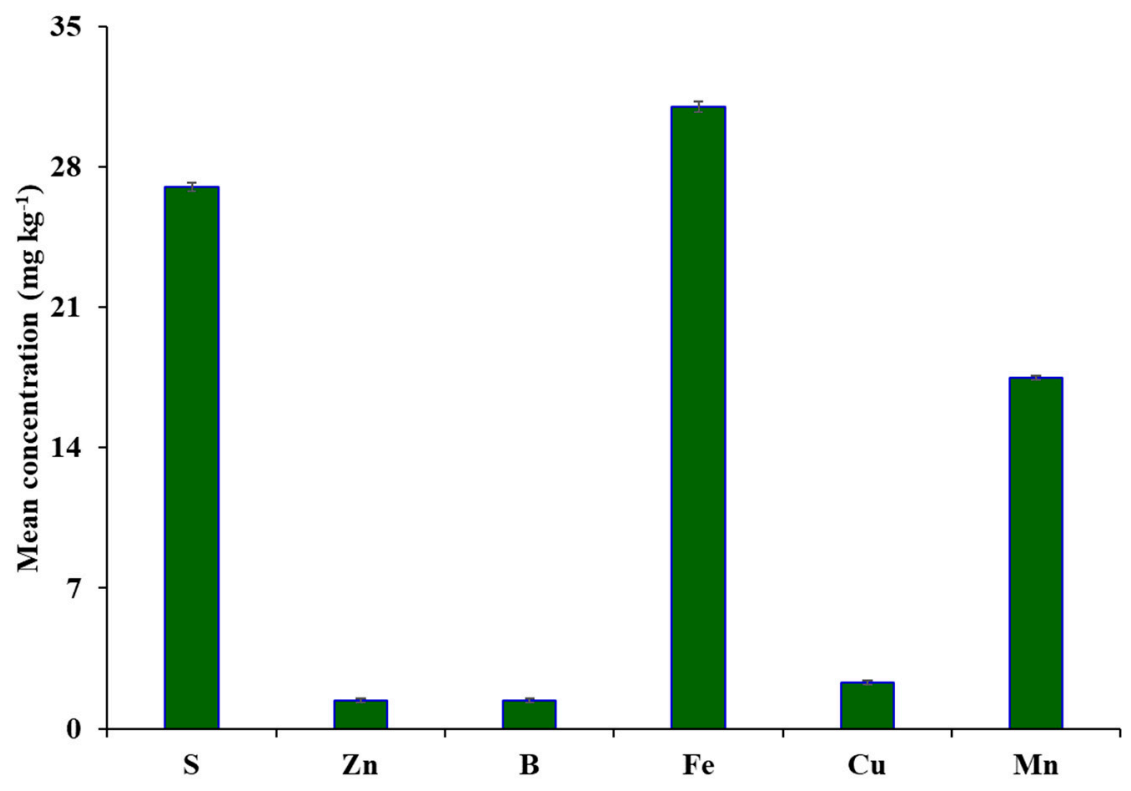

Figure 1. Mean concentration of available $S$ and micronutrients in agricultural soils of India. Error bars indicate stand error of the means.

About $7.90 \%, 28.6 \%$ and $14.7 \%$ of the sampled sites were acute deficient $\left(\leq 0.30 \mathrm{mg} \mathrm{kg}^{-1}\right)$, deficient $\left(>0.30-\leq 0.60 \mathrm{mg} \mathrm{kg}^{-1}\right)$ and latent deficient $\left(>0.60-\leq 0.90 \mathrm{mg} \mathrm{kg}^{-1}\right)$ in available $\mathrm{Zn}$, respectively (Figure 2). Meanwhile, $12.7 \%, 14.8 \%$ and $21.3 \%$ of the sampled sites were marginally sufficient $\left(>0.90-\leq 1.20 \mathrm{mg} \mathrm{kg}^{-1}\right)$, adequate $\left(>1.20-\leq 1.80 \mathrm{mg} \mathrm{kg}^{-1}\right)$ and high $\left(>1.80 \mathrm{mg} \mathrm{kg}^{-1}\right)$ in available $\mathrm{Zn}$, respectively. More than $30-\leq 40 \%$ of the sampled sites in 68 districts, $>40-\leq 50 \%$ of samples in 57 districts and $>50 \%$ of the sampled sites in 131 districts were deficient (acute deficient + deficient) in available $\mathrm{Zn}$. More than $50 \%$ of the sampled sites in 16 districts of Bihar, 40 districts of Madhya Pradesh, 13 districts of Maharashtra and 23 districts of Tamil Nadu were deficient in available $\mathrm{Zn}$.

About $4.00 \%, 19.2 \%$ and $21.5 \%$ of the sampled sites were acute deficient $\left(\leq 0.20 \mathrm{mg} \mathrm{kg}^{-1}\right)$, deficient $\left(>0.20-\leq 0.50 \mathrm{mg} \mathrm{kg}^{-1}\right)$ and latent deficient $\left(>0.50-\leq 0.70 \mathrm{mg} \mathrm{kg}^{-1}\right)$ in available B, respectively (Figure 2). Meanwhile, $12.1 \%, 11.4 \%$ and $31.7 \%$ of the sampled sites were marginally sufficient $\left(>0.70-\leq 0.90 \mathrm{mg} \mathrm{kg}^{-1}\right)$, adequate $\left(>0.90-\leq 1.10 \mathrm{mg} \mathrm{kg}^{-1}\right)$ and high $\left(>1.10 \mathrm{mg} \mathrm{kg}^{-1}\right)$ in available $B$, respectively. More than $30-\leq 40 \%$ of the sampled sites in 75 districts, $>40-\leq 50 \%$ of the sampled sites in 57 districts and $>50 \%$ of the sampled sites in 86 districts were deficient (acute deficient + deficient) in available B. More than 50\% of the sampled sites in 6 districts each of Assam and Karnataka, 7 districts of Jharkhand, 
10 districts of Kerala, 15 districts of Odisha and 5 districts each of Maharashtra, Telangana and West Bengal were deficient in available B.

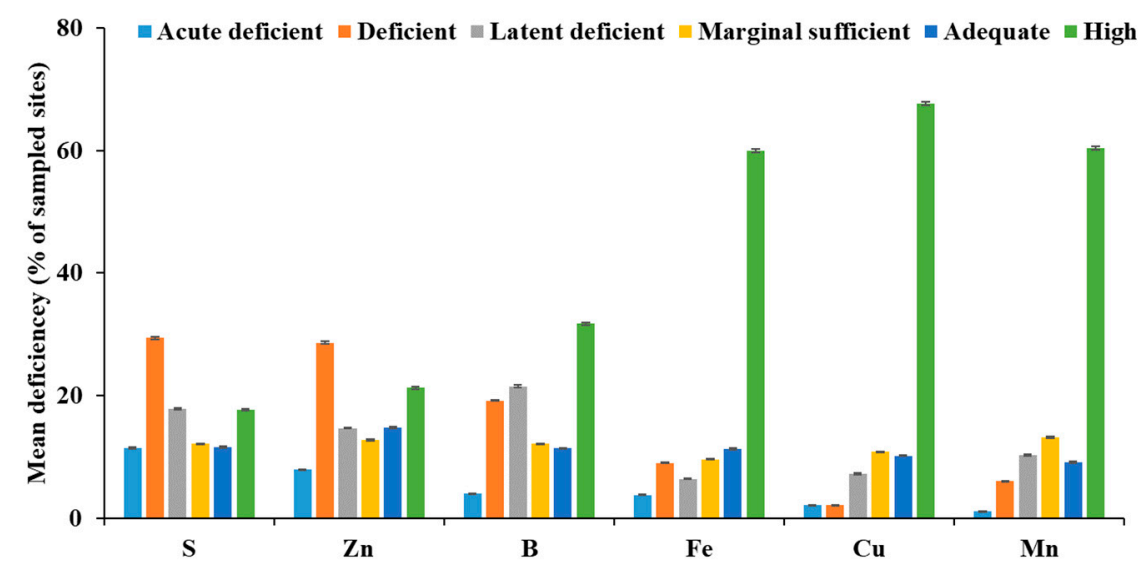

Figure 2. Mean deficiency of available $S$ and micronutrients in agricultural soils of India. Error bars indicate stand error of the means.

About $3.80 \%, 9.00 \%$ and $6.40 \%$ of the sampled sites were acute deficient $\left(\leq 2.50 \mathrm{mg} \mathrm{kg}^{-1}\right)$, deficient $\left(>2.50-\leq 4.50 \mathrm{mg} \mathrm{kg}^{-1}\right)$ and latent deficient $\left(>4.50-\leq 6.50 \mathrm{mg} \mathrm{kg}^{-1}\right)$ in available $\mathrm{Fe}$, respectively (Figure 2). Meanwhile, $9.60 \%, 11.3 \%$ and $59.9 \%$ of the sampled sites were marginally sufficient $\left(>6.50-\leq 8.50 \mathrm{mg} \mathrm{kg}^{-1}\right)$, adequate $\left(>8.50-\leq 10.5 \mathrm{mg} \mathrm{kg}^{-1}\right)$ and high $\left(>10.5 \mathrm{mg} \mathrm{kg}^{-1}\right)$ in available Fe, respectively. More than $15-\leq 20 \%$ of the sampled sites in 55 districts, $>20-\leq 25 \%$ of samples in 17 districts and $>25 \%$ of the sampled sites in 83 districts were deficient (acute deficient + deficient) in available Fe. More than $25 \%$ of the sampled sites in 17 districts of Gujarat, 14 districts of Maharashtra, 8 districts of Rajasthan and 9 districts of Uttar Pradesh were deficient in available Fe.

About $2.10 \%, 2.10 \%$ and $7.20 \%$ of the sampled sites were acute deficient $\left(\leq 0.20 \mathrm{mg} \mathrm{kg}^{-1}\right)$, deficient $\left(>0.20-\leq 0.40 \mathrm{mg} \mathrm{kg}^{-1}\right)$ and latent deficient $\left(>0.40-\leq 0.60 \mathrm{mg} \mathrm{kg}^{-1}\right)$ in available $\mathrm{Cu}$, respectively (Figure 2 ). Meanwhile, $10.8 \%, 10.2 \%$ and $67.6 \%$ of the sampled sites were marginally sufficient $\left(>0.60-\leq 0.80 \mathrm{mg} \mathrm{kg}^{-1}\right)$, adequate $\left(>0.80-\leq 1.00 \mathrm{mg} \mathrm{kg}^{-1}\right)$ and high $\left(>1.00 \mathrm{mg} \mathrm{kg}^{-1}\right)$ in available $\mathrm{Cu}$. Out of 615 districts, $>15-\leq 20 \%$ of the sampled sites in 13 districts, $>20-\leq 25 \%$ of the sampled sites in 8 districts and $>25 \%$ of the sampled sites in 5 districts were deficient (acute deficient + deficient) in available $\mathrm{Cu}$. More than $25 \%$ of the sampled sites in one district of Haryana, three districts of Tamil Nadu and one district of Odisha were deficient in available $\mathrm{Cu}$.

About $1.10 \%, 6.00 \%$ and $10.3 \%$ of the sampled sites were acute deficient $\left(\leq 1.00 \mathrm{mg} \mathrm{kg}^{-1}\right)$, deficient $\left(>1.00-\leq 3.00 \mathrm{mg} \mathrm{kg}^{-1}\right)$ and latent deficient $\left(>3.00-\leq 5.00 \mathrm{mg} \mathrm{kg}^{-1}\right)$ in available Mn, respectively (Figure 2). Meanwhile, $13.2 \%, 9.10 \%$ and $60.4 \%$ of the sampled sites were marginally sufficient $\left(>5.00-\leq 7.00 \mathrm{mg} \mathrm{kg}^{-1}\right)$, adequate $\left(>7.00-\leq 9.00 \mathrm{mg} \mathrm{kg}^{-1}\right)$ and high ( $>9.00 \mathrm{mg} \mathrm{kg}^{-1}$ ) in available Mn, respectively. More than $15-\leq 20 \%$ of the sampled sites in 21 districts, $>20-\leq 25 \%$ of samples in 14 districts and $>25 \%$ of the sampled sites in 41 districts were deficient (acute deficient + deficient) in available Mn. More than 25\% of the sampled sites in 4 districts of Bihar, 7 districts each of Jammu and Kashmir, Punjab and Rajasthan, 1 district each of Haryana, Himachal Pradesh, Tamil Nadu and Telangana and 12 districts of Uttar Pradesh were deficient in available Mn.

\subsection{Distribution of Multi-Nutrient Deficiencies of S, Zn, B, Fe, Cu and $\mathrm{Mn}$}

Two or more nutrient deficiencies were recorded in $0.10-9.30 \%$ of soils (Figure 3). The mean deficiency of $\mathrm{S}+\mathrm{Zn}$ was in $9.30 \%$ of the sampled sites (varying from $0.10-29.9 \%$ of the sampled sites for different states). It was predominantly prevalent in different districts of Bihar, Gujarat, Karnataka, Madhya Pradesh, Odisha, Rajasthan, Uttar Pradesh and Maharashtra (Figure 4). More than $20 \%$ of the sampled sites in 9 districts of Gujarat, 
25 districts of Madhya Pradesh, 8 districts of Odisha and 10 districts of Rajasthan were deficient in $\mathrm{S}+\mathrm{Zn}$. The deficiency of $\mathrm{Zn}+\mathrm{B}$ varied from $0.60-20.3 \%$ of the sampled sites in different states with a mean value of $8.70 \%$. Its prevalence in states such as Bihar, Karnataka, Odisha and Tamil Nadu was higher (Figure 5).

More than $20 \%$ of the sampled sites in 16 districts of Bihar, 5 districts each of Karnataka and Telangana, 13 districts of Odisha and 7 districts of Tamil Nadu were deficient in $\mathrm{Zn}+$ B. The deficiency of $S+B$ varied widely in different states with mean value of $7.00 \%$. A relatively higher percentage of the sampled sites in Jharkhand, Karnataka, Kerala, Manipur, Odisha, Uttarakhand and West Bengal state were deficient in S + B (Figure 6). More than $20 \%$ of the sampled sites in 6 districts each of Jharkhand and Manipur, 9 districts each of Karnataka and Kerala, 14 districts of Odisha and 5 districts of Telangana were deficient in $\mathrm{S}+\mathrm{B}$. On average, $5.80 \%$ of the sampled sites were deficient in $\mathrm{Zn}+\mathrm{Fe}$. A relatively higher percentage of the sampled sites of Gujarat, Karnataka, Maharashtra and Rajasthan were deficient in $\mathrm{Zn}+\mathrm{Fe}$ (Figure 7 ). More than $20 \%$ of the sampled sites in nine districts of Gujarat, five districts each of Madhya Pradesh and Maharashtra and seven districts of Rajasthan had Zn + Fe deficiency. A higher percentage of the sampled sites of Goa, Jammu and Kashmir and Rajasthan were deficient in $\mathrm{Zn}+\mathrm{Mn}$, with a national average of 3.4\% (Figure 8). Deficiencies of S + Fe (Figure 9), $\mathrm{Zn}+\mathrm{Cu}$ and Fe $+\mathrm{B}$ were recorded in 3.30\%, $2.80 \%$ and $2.70 \%$ of the sampled sites, respectively, and were scattered across the country. Deficiencies of $S+$ Fe was higher in Gujarat, Haryana, Rajasthan and Uttar Pradesh.

Three-nutrient deficiencies such as $\mathrm{S}+\mathrm{Zn}+\mathrm{B}, \mathrm{S}+\mathrm{Zn}+\mathrm{Fe}$ and $\mathrm{Zn}+\mathrm{Fe}+\mathrm{B}$ were recorded in $2.60 \%, 1.70 \%$ and $1.20 \%$ of the sampled sites, respectively. A relatively higher percentage of the sampled sites in Bihar, Goa, Karnataka and Odisha were deficient in $\mathrm{S}+\mathrm{Zn}+\mathrm{B}$. Moreover, $\mathrm{S}+\mathrm{Zn}+$ Fe deficiency was more prevalent in soils of Gujarat, Haryana, Maharashtra and Rajasthan. A higher percentage of the sampled sites in Bihar and Karnataka were deficient in $\mathrm{Zn}+\mathrm{Fe}+\mathrm{B}$. More than $20 \%$ of the sampled sites in one district each of Bihar, Chhattisgarh, Karnataka and Madhya Pradesh and five districts of Odisha were deficient in S $\mathrm{Zn}+\mathrm{B}$. More than $20 \%$ of the sampled sites in one district each of Haryana, Karnataka, Maharashtra and Uttar Pradesh and two districts each of Madhya Pradesh and Rajasthan were deficient in $\mathrm{S}+\mathrm{Zn}+$ Fe. More than three-nutrient deficiencies including $\mathrm{Zn}+\mathrm{Fe}+\mathrm{Cu}+\mathrm{Mn}$ and $\mathrm{Zn}+\mathrm{Fe}+\mathrm{Cu}+\mathrm{Mn}+\mathrm{B}$ were less prevalent, recorded in only $0.30 \%$ and $0.10 \%$ of the sampled sites, respectively. Less than $5 \%$ of the sampled sites in 13 districts of Bihar, 7 districts each of Punjab and Uttar Pradesh and 16 districts of Tamil Nadu were deficient in $\mathrm{Zn}+\mathrm{Fe}+\mathrm{Cu}+\mathrm{Mn}$. Meanwhile, less than 5\% of the sampled sites in 13 districts of Bihar, 4 districts of Punjab and 10 districts of Tamil Nadu were deficient in $\mathrm{Zn}+\mathrm{Fe}+\mathrm{Cu}+\mathrm{Mn}+\mathrm{B}$.

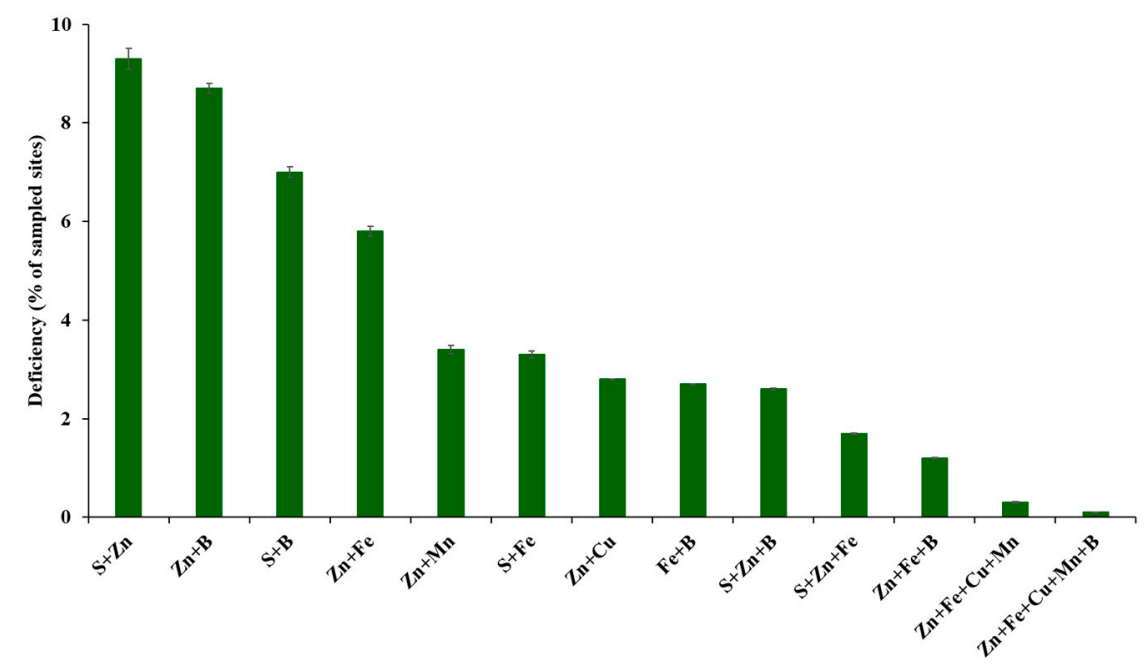

Figure 3. Mean deficiency of two or more nutrients ( $\mathrm{S}$ and micronutrients) in soils of different states of India. Error bars indicate stand error of the means. 


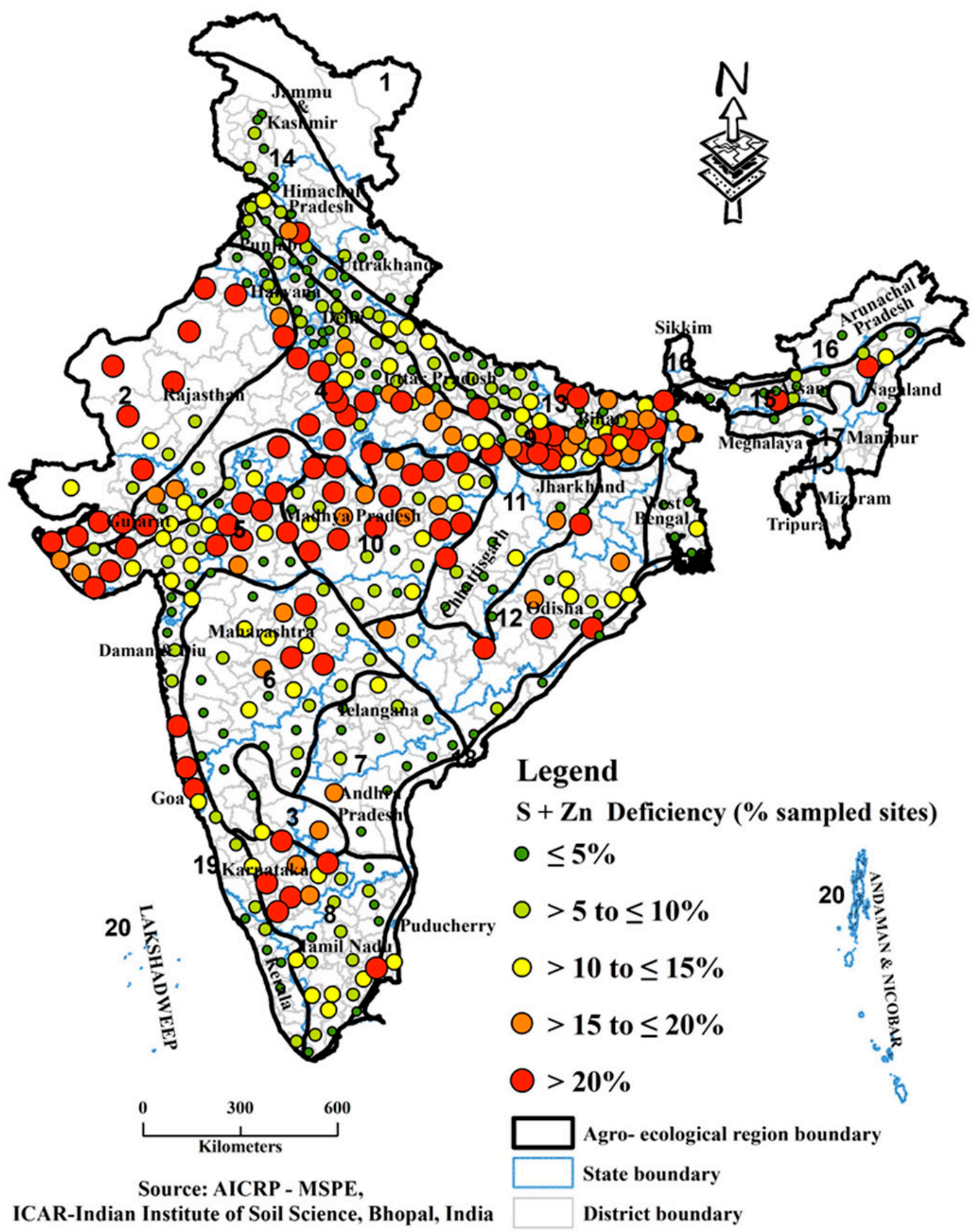

Figure 4. Distribution of $\mathrm{S}+\mathrm{Zn}$ deficiency in soils (\% of sampled sites) of different parts of India. Number denotes agro-ecological regions. 


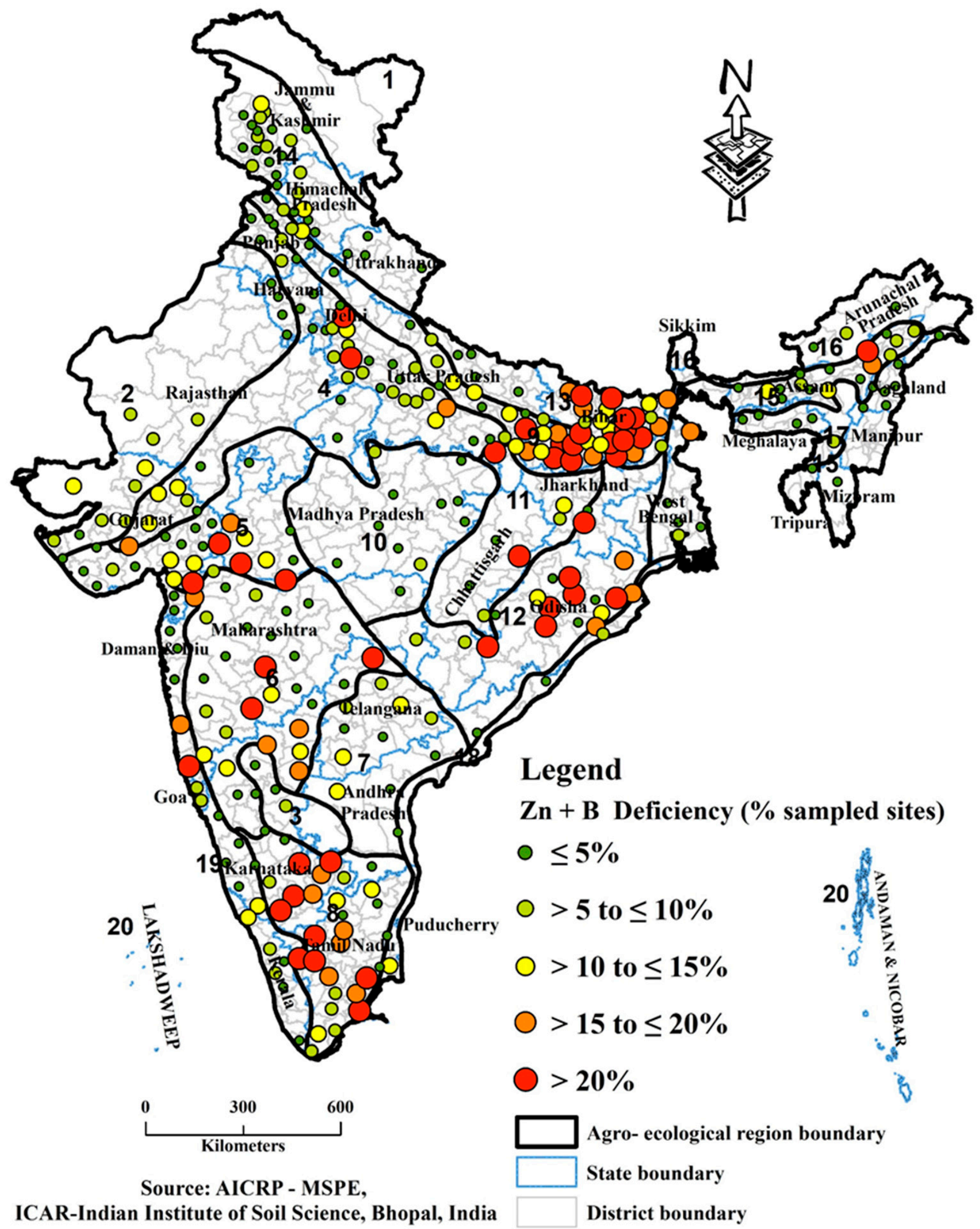

Figure 5. Distribution of $\mathrm{Zn}+\mathrm{B}$ deficiency in soils (\% of sampled sites) of different parts of India. Number denotes agro-ecological regions. 


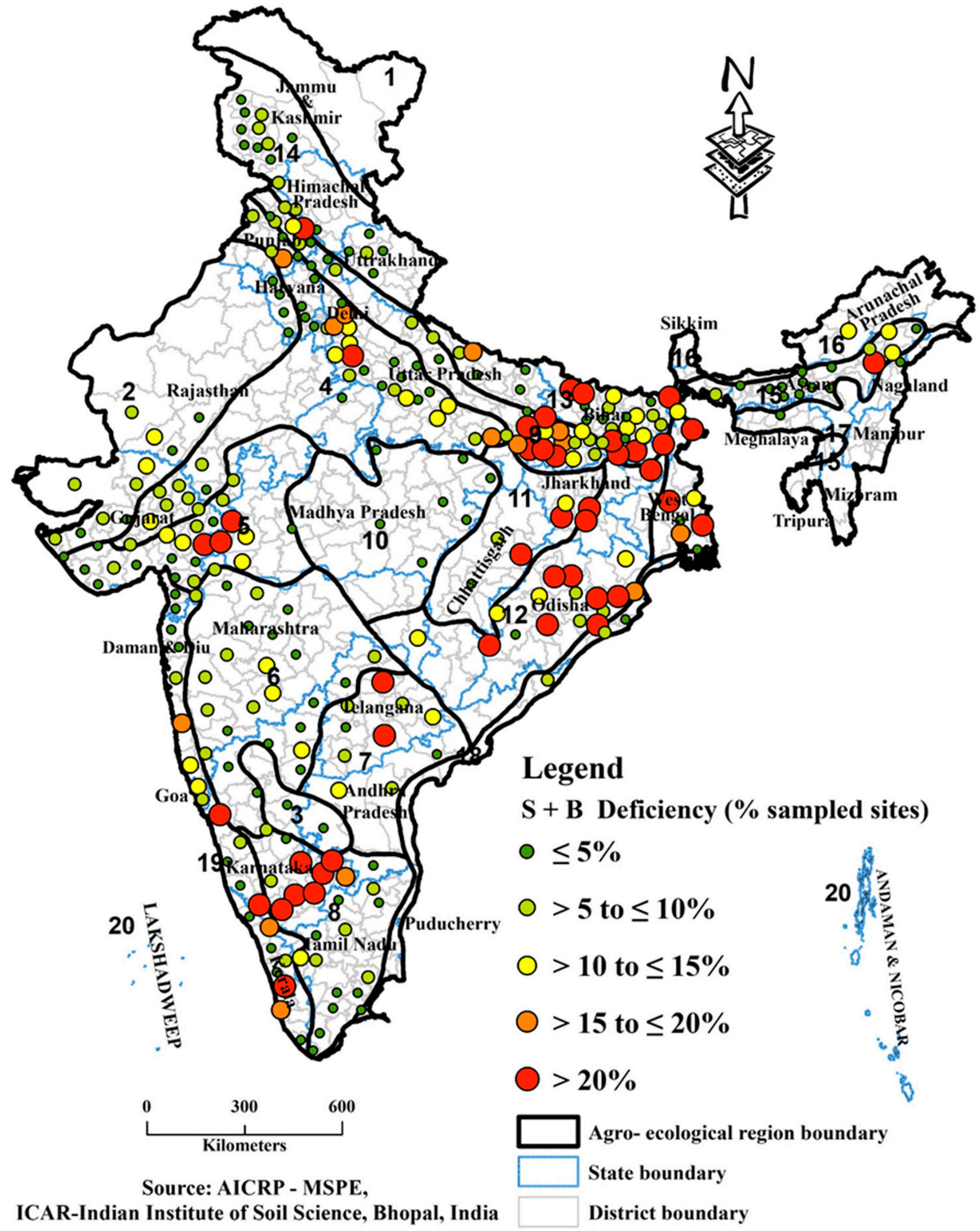

Figure 6. Distribution of S + B deficiency in soils (\% of sampled sites) of different parts of India. Number denotes agro-ecological regions. 


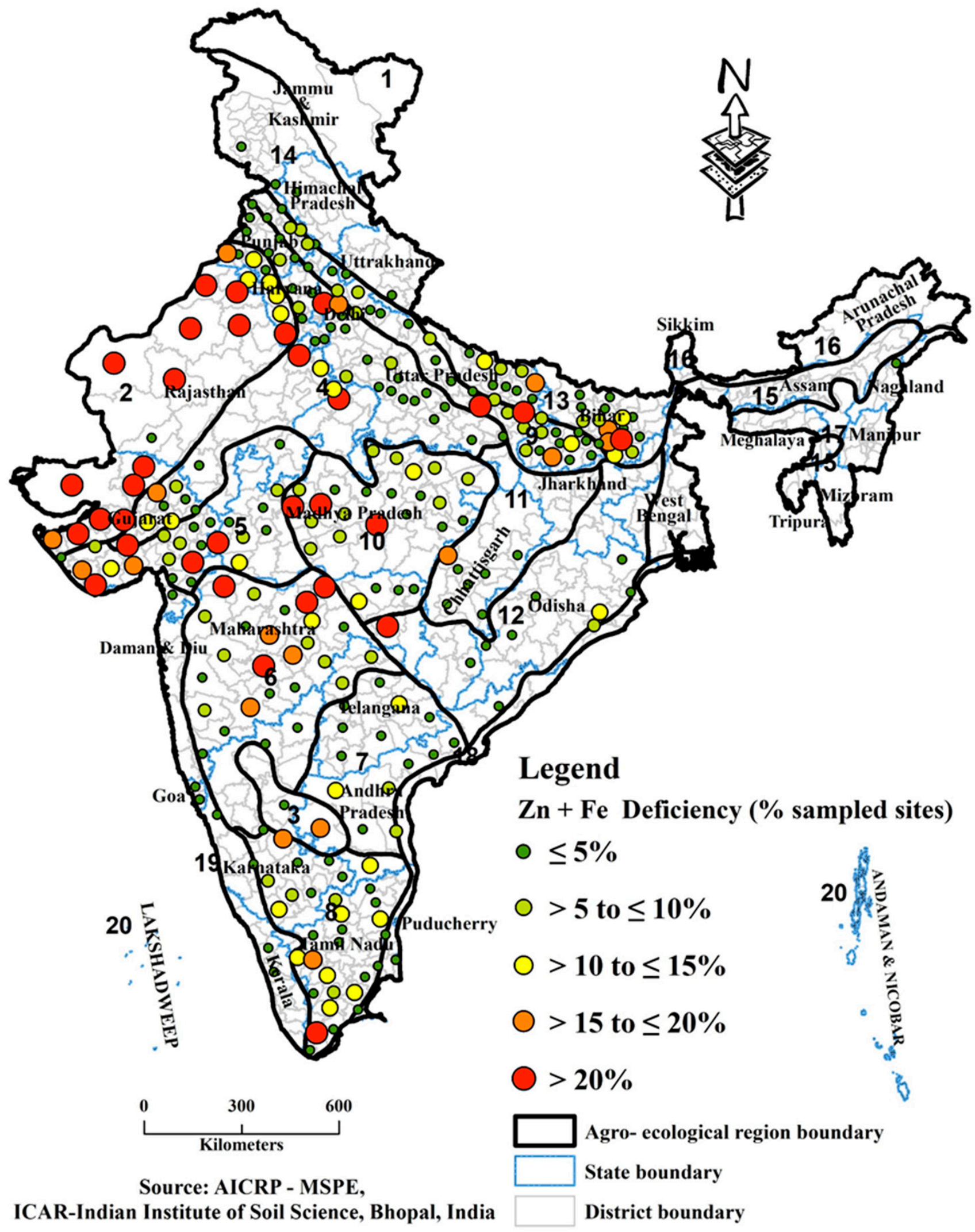

Figure 7. Distribution of $\mathrm{Zn}+$ Fe deficiency in soils (\% of sampled sites) of different parts of India. Number denotes agro-ecological regions. 


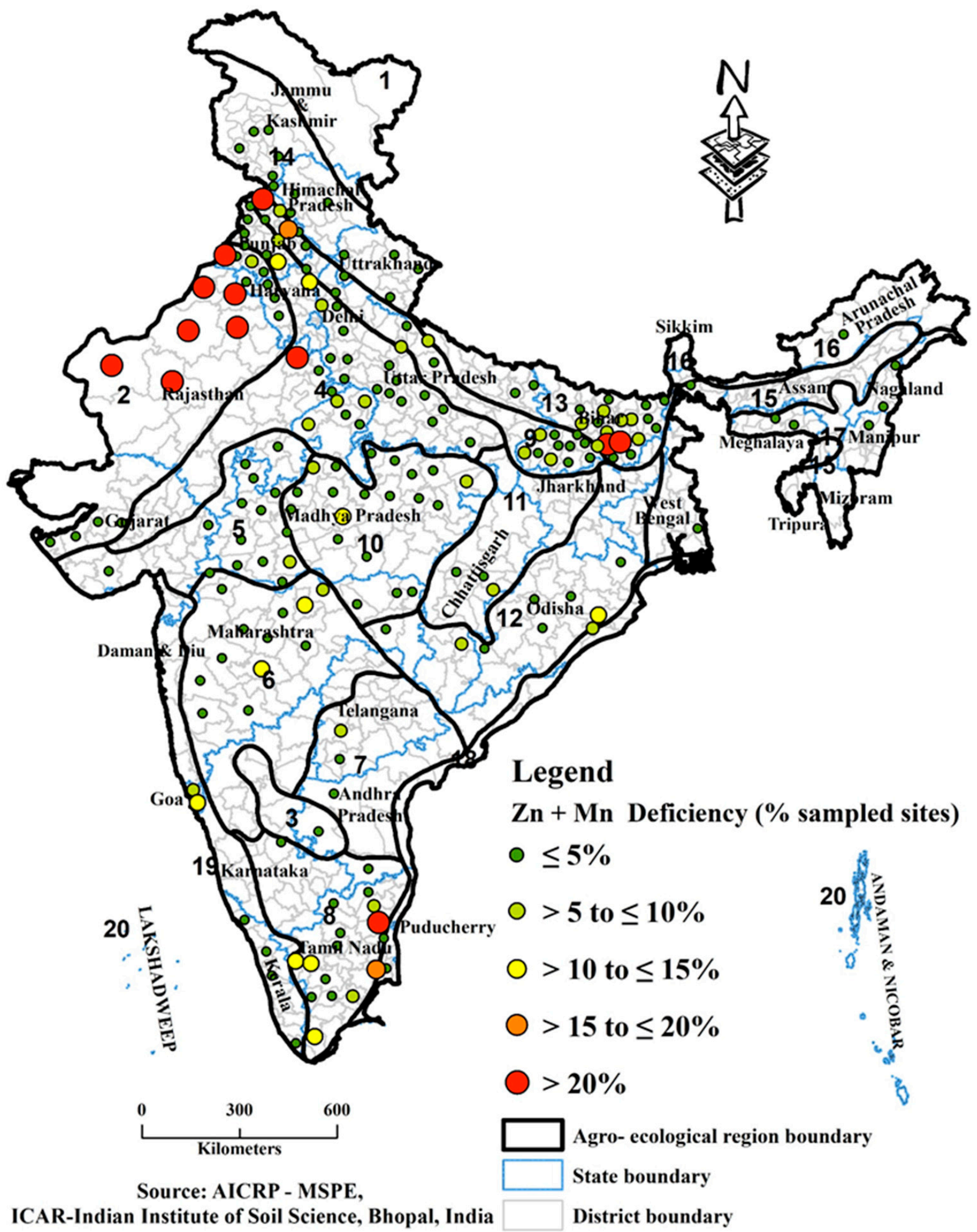

Figure 8. Distribution of $\mathrm{Zn}+\mathrm{Mn}$ deficiency in soils (\% of sampled sites) of different parts of India. Number denotes agro-ecological regions. 


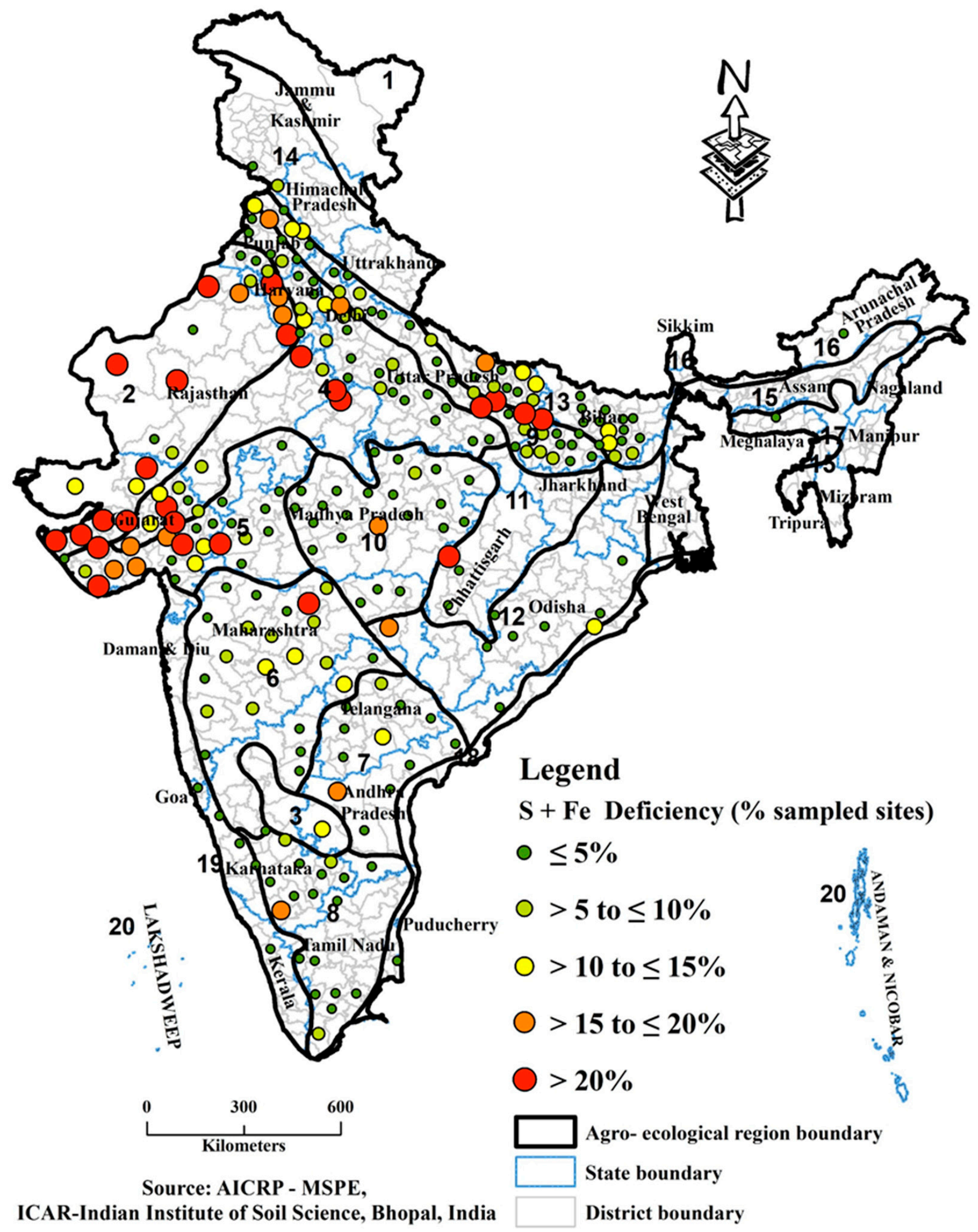

Figure 9. Distribution of S+ Fe deficiency in soils (\% of sampled sites) of different parts of India. Number denotes agro-ecological regions. 


\section{Discussion}

Proper understanding of the status of available $\mathrm{S}$ and micronutrients and their deficiencies in different soils is very much essential for effective fertilizer management in different soil-crop situations. Furthermore, it is useful for the production and distribution of $\mathrm{S}$ and micronutrients-based fertilizers for different areas.

\subsection{Concentration of Available $S, \mathrm{Zn}, \mathrm{B}, \mathrm{Fe}, \mathrm{Cu}$ and $\mathrm{Mn}$}

The concentrations of available $\mathrm{S}, \mathrm{Zn}, \mathrm{B}, \mathrm{Fe}, \mathrm{Cu}$ and $\mathrm{Mn}$ in soils of India varied widely (with CV values of $111 \%$ to $338 \%$ ) with a mean concentration of $27.0 \pm 29.9 \mathrm{mg} \mathrm{kg}^{-1}$ for available S, $1.40 \pm 1.60 \mathrm{mg} \mathrm{kg}^{-1}$ for available $\mathrm{Zn}, 1.40 \pm 4.70 \mathrm{mg} \mathrm{kg}^{-1}$ for available B, $31.0 \pm 52.2 \mathrm{mg} \mathrm{kg}^{-1}$ for available $\mathrm{Fe}, 2.30 \pm 3.50 \mathrm{mg} \mathrm{kg}^{-1}$ for available $\mathrm{Cu}$ and $17.5 \pm 21.4 \mathrm{mg} \mathrm{kg}^{-1}$ for available Mn (Table 3). This is in line with the finding of Scherer [30], who reported wide variations in available $S$ concentrations in soils of different parts of the world. Mathew et al. [31] also reported the mean concentration of available $\mathrm{Zn}$ $2.80 \pm 0.2 \mathrm{mg} \mathrm{kg}^{-1}$, available Fe $130 \pm 6.90 \mathrm{mg} \mathrm{kg}^{-1}$, available $\mathrm{Mn} 193 \pm 20.5 \mathrm{mg} \mathrm{kg}^{-1}$, available B $0.68 \pm 1.10 \mathrm{mg} \mathrm{kg}^{-1}$ and available Cu $8.40 \pm 0.80 \mathrm{mg} \mathrm{kg}^{-1}$ in surface soils of Mount Kilimanjaro's slopes in Tanzania. Silva et al. [32] reported the mean concentration of available Fe $66.6 \pm 56.0 \mathrm{mg} \mathrm{kg}^{-1}$, available Mn $12.2 \pm 14.4 \mathrm{mg} \mathrm{kg}^{-1}$, available $\mathrm{Zn}$ $2.30 \pm 1.30 \mathrm{mg} \mathrm{kg}^{-1}$ and available Cu $1.10 \pm 0.80 \mathrm{mg} \mathrm{kg}^{-1}$ in surface soils of sugarcaneproducing regions of Brazil. The variations in available $S$ and micronutrients in soils is attributed to soil factors, plant factors and soil-crop management practices $[15,30,33,34]$. Furthermore, presence of organic matter, plant residues and S-containing salts contribute towards variations in available $S$ concentration in soils [35]. The available concentrations of $S$ and micronutrients in soils depend more on the level of weathering of rocks [15]. The highly weathered tropical soils have the lowest $\mathrm{S}$ and micronutrient concentrations. Soil factors, namely $\mathrm{pH}$, soil organic matter, redox potential, biological activity, clay content and cation exchange capacity, and anthropogenic activities predominantly influence soil properties and micronutrient availability $[17,36]$. Moreover, plant factors such as type and nature of plant, rooting morphology, root secretions and plant-microbe associations influence micronutrient availability $[37,38]$.

\subsection{Distribution of Single Nutrient Deficiencies of S, Zn, B, Fe, Cu and Mn}

About $40.8 \%$ and $17.8 \%$ of the sampled sites were deficient (acute deficient + deficient) and latently deficient in available $\mathrm{S}$, respectively (Figure 2). The extent of $\mathrm{S}$ deficiency was different in districts of various states of India. More than $50 \%$ of the sampled sites of a large number of districts in states including Gujarat, Madhya Pradesh, Manipur, Odisha and Rajasthan were deficient in available S. The variations in S deficiency in soils of different parts of the country is ascribed to growing of crops requiring $S$, and nil or insufficient application of $S$ fertilizers. This highlights the fact that farmers need to pursue site-specific $\mathrm{S}$ management based on different soil-crop situations, as the extent of deficiency in soils and cop requirements varies. Corroborating our findings, several researchers reported crop responses to various doses of $S$ application in different parts of India [16,39-41].

There were deficiencies (acute deficient + deficient) of available $\mathrm{Zn}, \mathrm{B}, \mathrm{Fe}, \mathrm{Cu}$ and $\mathrm{Mn}$ in $36.5 \%, 23.2 \%, 12.8 \%, 4.20 \%$ and $7.10 \%$ of the sampled sites, respectively (Figure 2 ). Some soils also exhibited latent deficiency in these micronutrients. Alloway [12] also reported the deficiency of micronutrients in soils of different countries of the world. Like $S$ deficiency, the extent of micronutrient deficiency varies in different districts of various states. The deficiency of $\mathrm{Zn}$ at various levels prevails in almost all states of the country. Most of the $\mathrm{Zn}$ deficiency is observed in soils with high $\mathrm{pH}$, coarse textured, calcareous, low in organic carbon content and under intense cultivation. Like Zn deficiency, B deficiency also prevailed in different states of India. It is more prevalent in the leached sandy, highly calcareous, limed acid and lateritic soils. The extent of B deficiency was higher in eastern states of India, which is attributed to excess leaching in sandy loam soils and alluvial and loess deposits. 
The deficiency of Fe was more prevalent in western states including Gujarat, Maharashtra and Rajasthan. It was also prevalent in soils of Bihar, Uttar Pradesh, Karnataka and Telangana. The deficiency of Fe in soils of these states is attributed to the higher soil $\mathrm{pH}$ and prevailing moisture stress conditions, which leads to conversion of ferrous $\left(\mathrm{Fe}^{2+}\right)$ to ferric $\left(\mathrm{Fe}^{3+}\right)$ form of Fe. Copper deficiency was present in the limited samples. More than $20 \%$ of sampled sites in 13 districts of Assam, Haryana, Odisha, Rajasthan and Tamil Nadu had $\mathrm{Cu}$ deficiency. The deficiency of $\mathrm{Cu}$ in these soils is because of sandy textured, calcareous and eluviated soils rich in organic matter. The extent of Mn deficiency was more prevalent in states including Bihar, Haryana, Jammu and Kashmir, Punjab, Rajasthan, Tamil Nadu, Telangana and Uttar Pradesh. The deficiency of Mn in soils is attributed to the presence of low total content of Mn, calcareous soil, heavily limed acid soil, coarse textured soils and low moisture content. Our findings regarding the prevalence of micronutrient deficiencies in soils of different states of India are corroborated by the reports of the crop responses to application of micronutrients [20,42,43]. Crop responses vary with soil-crop contexts. Therefore, the farmers need to apply micronutrient fertilizers based on the extent of deficiency in soils and crop demands under various soil-crop situations. Further, for enriching consumable agricultural produce with $\mathrm{Zn}$ and $\mathrm{Fe}$, it is very much essential to maintain the sufficient levels of plant available $\mathrm{Zn}$ and Fe in soils or readily available pools of $\mathrm{Zn}$ and Fe in plant parts [18]. This could be achieved by supplying $\mathrm{Zn}$ and Fe fertilizers to the soils and plants based on $\mathrm{Zn}$ and Fe status in soil and crop requirements.

\subsection{Distribution of Multi-Nutrient Deficiencies of S, Zn, B, Fe, Cu and $\mathrm{Mn}$}

Along with the single nutrient deficiency, deficiencies of two or more nutrients ( $S$ and micronutrients) were prevalent in different states. The average percent of samples showing multi-nutrient deficiencies followed the order: $S+Z n>Z n+B>S+B>Z n+$ $\mathrm{Fe}>\mathrm{Zn}+\mathrm{Mn}>\mathrm{S}+\mathrm{Fe}>\mathrm{Zn}+\mathrm{Cu}>\mathrm{Fe}+\mathrm{B}>\mathrm{S}+\mathrm{Zn}+\mathrm{B}>\mathrm{S}+\mathrm{Zn}+\mathrm{Fe}>\mathrm{Zn}+\mathrm{Fe}+\mathrm{B}$ $>\mathrm{Zn}+\mathrm{Fe}+\mathrm{Cu}+\mathrm{Mn}>\mathrm{Zn}+\mathrm{Fe}+\mathrm{Cu}+\mathrm{Mn}+\mathrm{B}$. However, the extent of multi-nutrient deficiencies was different in various states and AERs. The states of Goa, Madhya Pradesh, Odisha and Rajasthan had S + Zn deficiency in $>15 \%$ of sampled sites. The AER 5, 8, 9, 10 and 13 had higher percent of $S+Z n$ deficiency. Similarly, the higher percentage of sampled sites of Bihar, Karnataka, Odisha and Tamil Nadu (of AER 5, 8, 12 and 13) had $\mathrm{Zn}+\mathrm{B}$ deficiency. The percent deficiency of $\mathrm{S}+\mathrm{B}$ was more in AER 5, 8, 9, 12 and 13. The higher percentage of sampled sites were deficient in $\mathrm{Zn}+\mathrm{Fe}$ in AER 2, 5, 6 and 8. This spatial variability in the distribution of deficiencies is attributed to differences in prevailing climate parameters, soils, cultivated crops and adoption of different soil-crop management practices (Tables 1 and 2). This warrants application of customized fertilizers according to the nutrient deficiencies in soils and crop requirements, in different districts, states and AERs, for better soil health, sustainable crop production and improved crop quality $[44,45]$. The information generated from this study could be utilized by the planners, policymakers and fertilizer industries in the production and supply of the right kind of $S$ and micronutrients-based customized fertilizers for different districts, states and AERs of India. Presently, some customized grades of fertilizers are available for farmers [46] and there are some reports of crop responses to the application of customized fertilizers in India $[47,48]$. However, there is need for the development of S and micronutrientsbased customized fertilizers for different districts of India considering $S$ and micronutrient deficiencies and crop needs. This will help in a greater way for obtaining sustainable crop production, better crop quality and animal and human health.

\section{Conclusions}

The study revealed a wide variation in the concentrations of available $S$ and micronutrients in agricultural soils of India. There were varied levels of deficiencies (acute deficient + deficient + latent deficient) for available S (58.6\%), available Zn (51.2\%), available B (44.7\%), available Fe (19.2\%), available Cu (1104\%) and available Mn (17.4\%). The distribution of single and multi-nutrient deficiencies of $S$ and micronutrients in different districts, 
states and AERs of India was different. There is a need for $\mathrm{S}$ and micronutrient application based on the soil deficiency status in various districts, states and AERs of India, as well as crop requirements for sustainable crop production, enrichment of nutrients in crops and better animal and human health. Based on multi-nutrient deficiency, the right kind of $\mathrm{S}$ and micronutrients-based customized fertilizers may be developed and supplied for use in different regions of India. This type of study needs to be carried out periodically to obtain precise information pertaining to exact levels of $S$ and micronutrient deficiencies to achieve strategic planning of balanced and site-specific nutrient management. Single and multi-nutrient deficiencies may be assessed in the agricultural soils of other parts of the world for efficient use of $S$ and micronutrients in order to achieve food and nutritional security and better animal and human health.

Author Contributions: All authors contributed to the design of the study. A.K.S. (Arvind Kumar Shukla), S.K.B., S.D., A.G. and C.P. collected the samples, relevant data and conducted analysis. A.K.S. (Anil Kumar Singh) and S.K.B. wrote the first draft. A.K.S. (Arvind Kumar Shukla), S.K.B., A.K.P., C.S.R., S.D., A.G., S.K.C. and A.K.S. (Anil Kumar Singh) edited and revised the manuscript. All authors have agreed to the published version of the manuscript.

Funding: The study was funded by Indian Council of Agricultural Research, New Delhi.

Institutional Review Board Statement: Not applicable.

Informed Consent Statement: Not applicable.

Data Availability Statement: The data are available from the corresponding author upon reasonable request.

Acknowledgments: The authors thank the Indian Council of Agricultural Research, New Delhi, for supporting the study through All India Coordinated Research Project on Micro and Secondary Nutrients in Soils and Plants. The authors acknowledge their colleagues who extended logistic and technical support during the study.

Conflicts of Interest: The authors declare that they have no conflict of interest.

Animal Research: Not applicable.

Consent to Participate: The consent of all the participants of the study was obtained.

Consent for Publication: The consent for publication was obtained from all the participants of the study.

\section{References}

1. Singh, B.; Schulze, D.G. Soil Minerals and Plant Nutrition. Nat. Educ. Knowl. 2015, 6, 1.

2. Cogger, C.; Brown, S. Soil formation and nutrient cycling. In Sowing Seeds in the City; Brown, S., McIvor, K., Hodges, S.E., Eds.; Springer: Dordrecht, The Netherlands, 2016. [CrossRef]

3. Chapin, F.S. Patterns of nutrient absorption and use by plants from natural and man-modified environments. In Disturbance and Ecosystems. Ecological Studies (Analysis and Synthesis); Mooney, H.A., Godron, M., Eds.; Springer: Berlin/Heidelberg, Germany, 1983. [CrossRef]

4. Marschner, P. Marschner's Mineral Nutrition of Higher Plants; Academic Press: Adelaide, Australia, 2012. [CrossRef]

5. Bhatt, P.; Verma, A.; Verma, S.; Anwar, M.S.; Prasher, P.; Mudila, H.; Chen, S. Understanding phytomicrobiome: A potential reservoir for better crop management. Sustainability 2020, 12, 5446. [CrossRef]

6. Fendrihan, S.; Pop, C.E. Biotechnological potential of associated microorganism. Rom. Biotechnol. Lett. 2021, 26, 2700-2706. [CrossRef]

7. Brevik, E.C.; Slaughter, L.; Singh, B.R.; Steffan, J.J.; Collier, D.; Barnhart, P.; Pereira, P. Soil and human health: Current status and future needs. Air Soil Water Res. 2020, 13, 1-23. [CrossRef]

8. White, P.J.; Brown, P.H. Plant nutrition for sustainable development and global health. Annals Bot. 2010, 105, 1073-1080. [CrossRef] [PubMed]

9. Shukla, A.K.; Behera, S.K.; Pakhre, A.; Chaudhari, S.K. Micronutrients in soils, plants, animals and humans. Indian J. Fert. 2018, 14, 30-54.

10. Khurana, M.P.S.; Sadana, U.S. Bijay-Singh. Sulfur nutrition of crops in the Indo-Gangetic plains of south Asia. In Sulfur: A Missing Link between Soils, Crops, and Nutrition; Jez, J., Ed.; American Society of Agronomy: Madison, WI, USA, 2008; pp. 11-24. [CrossRef] 
11. Piotrowska-Dlugosz, A.; Siwik-Ziomek, A.; Dlugosz, J.; Gozdowski, D. Spatio-temporal variability of soil sulfur content and arylsulfatase activity at a conventionally managed arable field. Geoderma 2017, 295, 107-118. [CrossRef]

12. Alloway, B.J. Micronutrient Deficiencies in Global Crop Production; Springer: Dordrecht, The Netherlands, 2008. [CrossRef]

13. Shukla, A.K.; Behera, S.K.; Satyanarayana, T.; Majumdar, K. Importance of micronutrients in Indian agriculture. Better Crops South Asia 2019, 11, 6-10.

14. Kihara, J.; Bolo, P.; Kinyua, M.; Rurinda, J.; Pikki, K. Micronutrient deficiencies in African soils and the human nutritional nexus: Opportunities with staple crops. Environ. Geochem. Health 2020, 42, 3015-3033. [CrossRef] [PubMed]

15. Fageria, N.K.; Baligar, V.C.; Clark, R.B. Micronutrients in crop production. Adv. Agron. 2002, 77, 185-250. [CrossRef]

16. Shukla, A.K.; Behera, S.K. All India research project on micro- and secondary nutrients and pollutant elements in soils and plants: Research achievements and future thrusts. Indian J. Fert. 2019, 15, 522-543.

17. Manzeke, G.M.; Mtambanengwe, F.; Watts, M.J.; Hamilton, E.M.; Lark, R.M.; Broadley, M.R.; Mapfumo, P. Fertilizer management and soil type influence grain zinc and iron concentration under contrasting smallholder cropping systems in Zimbabwe. Sci. Rep. 2019, 9, 6445. [CrossRef]

18. Shukla, A.K.; Behera, S.K. Biofortification for overcoming zinc and iron malnutrition in Indian population: Current research status and way forward. Indian J. Fert. 2020, 16, 1262-1276.

19. Shah, F.; Wu, W. Soil and crop management strategies to ensure higher crop productivity within sustainable environments. Sustainability 2019, 11, 1485. [CrossRef]

20. Shukla, A.K.; Behera, S.K.; Singh, V.K.; Prakash, C.; Sachan, A.K.; Dhaliwal, S.S.; Srivastava, P.C.; Pachauri, S.P.; Tripathi, A.; Pathak, J.; et al. Pre-monsoon spatial distribution of available micronutrients and sulphur in surface soils and their management zones in Indian Indo-Gangetic Plain. PLoS ONE 2020, 15, e0234053. [CrossRef]

21. Steffan, J.J.; Brevik, E.C.; Burgess, L.C.; Cerda, A. The effect of soil on human health: An overview. Eur. J. Soil Sci. 2018, 69, 159-171. [CrossRef] [PubMed]

22. Behera, S.K.; Shukla, A.K.; Prakash, C.; Tripathi, A.; Kumar, A.; Trivedi, V. Establishing management zones of soil sulphur and micronutrients for sustainable crop production. Land Degrad. Dev. 2021, 32, 3614-3625. [CrossRef]

23. Soil Survey Staff. Keys to Soil Taxonomy; USDA-Natural Resources Conservation Service: Washington, DC, USA, 2014.

24. NBSSLUP. National Bureau of Soil Survey and Land Use Planning. 2021. Available online: https://www.nbsslup.in/assets/ uploads/clinks/Delineating\%20Agro-Ecological\%20Regions.pdf (accessed on 15 July 2021).

25. Gelfand, A.E.; Schliep, E.M. Spatial statistics and Gaussian processes: A beautiful marriage. Spatial Stat. 2016, 18, 86-104. [CrossRef]

26. Williams, C.H.; Steinbergs, A. Soil sulphur fractions as chemical indices of available sulphur in some Australian soils. Aust. J. Agril. Res. 1959, 10, 340-352. [CrossRef]

27. Lindsay, W.L.; Norvell, W.A. Development of a DTPA soil test for zinc, iron, manganese and copper. Soil Sci. Soc. Am. J. 1978, 42, 421-448. [CrossRef]

28. Gupta, U.C. A simplified method for determining hot-water soluble boron in podzol soils. Soil Sci. 1967, 103, 424-428. [CrossRef]

29. SAS Institute. The SAS System for Windows. Release 9.2; SAS Institute: Cary, NC, USA, 2011.

30. Scherer, H.W. Sulfur in soils. J. Plant Nutr. Soil Sci. 2009, 172, 326-335. [CrossRef]

31. Mathew, M.M.; Majule, A.E.; Marchant, R.; Sinclair, F. Variability of soil micronutrients concentration along the slopes of Mount Kilimanjaro, Tanzania. Appl. Env. Soil Sci. 2016, 9814316. [CrossRef]

32. Silva, R.C.F.; Silva, F.B.V.; Biondi, C.M.; Nascimento, C.W.A.; Oliveira, E.C.A. Assessing the content of micronutrients in soils and sugarcane in different pedogeological contexts of northeastern Brazil. Rev. Bras. Ciencia Solo 2019, 43, e0180228. [CrossRef]

33. White, J.G.; Zasoski, R.J. Mapping soil micronutrients. Field Crops Res. 1999, 60, 11-26. [CrossRef]

34. Rengel, Z. Availability of Mn, Zn and Fe in the rhizosphere. J. Soil Sci. Plant Nutr. 2015, 15, 397-409. [CrossRef]

35. Jez, J. Availability of sulfur to crops from soil and other sources. In Sulfur: A Missing Link between Soils, Crops, and Nutrition; Jez, J. American Society of Agronomy: Madison, WI, USA, 2008; pp. 59-82. [CrossRef]

36. Bungau, S.; Behl, T.; Aleya, L.; Bourgeade, P.; Aloui-Soss, B.; Purza, A.L.; Abid, A.; Samuel, A.D. Expatiating the impact of anthropogenic aspects and climatic factors on long-term soil monitoring and management. Environ. Sci. Pollut. Res. 2021, 28, 30528-30550. [CrossRef]

37. Samuel, A.D.; Bungau, S.; Tit, D.M.; Melinte, C.E.; Purza, L.; Bad, G.E. Effects of long-term application of organic and mineral fertilizers on soil enzymes. Rev. Chim. 2018, 69, 2608-2612. [CrossRef]

38. Samuel, A.D.; Bungau, S.; Fodor, I.K.; Tit, D.M.; Blidar, C.F.; David, T.; Melinte, C.E. Effects of liming and fertilization on the dehydrogenase and catalase activities. Rev. Chim. 2019, 70, 3464-3468. [CrossRef]

39. Singh, M.V.; Behera, S.K. All India Coordinated Research Project of Micro- and Secondary Nutrients and Pollutant Elements in Soils and Plants-A Profile; Research Bulletin No. 10; All India Coordinated Research Project of Micro- and Secondary Nutrients and Pollutant Elements in Soils and Plants; Indian Institute of Soil Science: Bhopal, India, 2011; pp. 1-57.

40. Aulakh, M.S. Crop responses to sulphur nutrition. In Sulphur in Plants; Abrol, Y.P., Ahmad, A., Eds.; Springer: Dordrecht, The Netherlands, 2003. [CrossRef]

41. Singh, V.K.; Dwivedi, B.S.; Shukla, A.K.; Kumar, V.; Gangwar, B.; Rani, M.; Singh, S.K.; Mishra, R.P. Status of available sulfur in soils of north-western Indo-Gangetic plain and western Himalayan region and responses of rice and wheat to applied sulfur in farmer's fields. Agri. Res. 2015, 4, 76-92. [CrossRef] 
42. Takkar, P.N.; Chhibba, I.M.; Mehta, S.K. Twenty Years of Coordinated Research on Micronutrients in Soils and Plants; Indian Institute of Soil Science: Bhopal, India, 1989.

43. Shukla, A.K.; Behera, S.K. Micronutrient fertilizers for higher productivity. Indian J. Fert. 2012, 8, $100-117$.

44. Tiwari, K.N. Relevance of customized fertilizers in the era of multi-nutrient deficiency. Indian J. Fert. 2010, 6, 76-86.

45. Majumdar, S.; Prakash, N.B. Prospects of customized fertilizers in Indian agriculture. Curr. Sci. 2018, 115, 242-248. [CrossRef]

46. FAI. Speciality Fertilizers and Micronutrient Statistics 2019-2020; The Fertilizer Association of India: New Delhi, India, 2020.

47. Dwivedi, S.K.; Meshram, M.R. Effect of customized fertilizer on productivity and nutrient uptake of rice (Oryza sativa). Indian J. Agron. 2014, 59, 247-250.

48. Mudalagiriyappa, B.; Raghavendra Goud, B.; Ramachandrappa, B.K.; Nanjappa, H.V. Influence of customized fertilizers on growth and yield of Finger Millet \{Eleusine coracana (L.) Gaertn.\} in Alfisols of southern India. Indian J. Dryland Agri. Res. Dev. 2015, 30, 50-54. [CrossRef] 